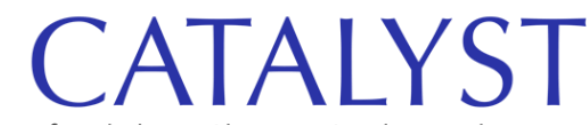

feminism, theory, technoscience

\title{
Cyborgs Unbound: \\ Feminist STS, Interdisciplinarity, and Graduate Education
}

\author{
Kiran Asher \\ University of Massachusetts, Amherst \\ kasher@umass.edu
}

Mel Y. Chen

University of California, Berkeley

melychen@berkeley.edu

Kareem Khubchandani

Tufts University

kareem.khubchandani@tufts.edu

Eli Nelson

Williams College

ewn2@williams.edu

Banu Subramaniam

University of Massachusetts, Amherst banu@wost.umass.edu 


\section{Abstract}

This Lab Meeting took place as a roundtable titled Cyborg Manifestations. Hosted at MIT in February 2020, it was part of the Boston-area Consortium for Graduate Studies in Gender, Culture, Women, and Sexuality's (GCWS) series Feminisms Unbound. The introduction maps the history and structure of the GCWS series and highlights how its rigorous commitment to interdisciplinary graduate education fosters feminist science and technology studies (STS) in the Boston area. The introduction also frames the remarks of the roundtable participants, who speak to drag queens, artificial intelligence, plant life, gender and environmental conservation, and objecthood. Five transcripts or "lab reports" highlight how the figure of the cyborg animates and reinvigorates feminist, queer, and trans approaches to technoscience.

\section{Introduction: Institutionalizing Interdisciplinarity}

\section{Kareem Khubchandani}

Donna Haraway's "Cyborg Manifesto," which was published in Socialist Review in 1985, was a watershed publication for many disciplines, hailing a poststructuralist turn in the study of gender and sexuality, forecasting the importance of Marxistfeminism to studies of the Anthropocene, and laying the ground for feminist approaches to the study of science and technology. Coming out amid a florescence of women's studies programs, this essay foregrounded the potential of fundamentally interdisciplinary inquiry for feminist scholarship. While Boston was certainly a vibrant scene of feminist activism, feminist scholarship and scholars were siloed by their various institutions and departmental affiliations. ${ }^{1}$ In 1988 a handful of feminist scholars from various institutions gathered around MIT professor Ruth Perry's kitchen table and dreamed up a cross-university consortium that could offer graduate-level courses in women's studies. The professors who conceived of the Consortium for Graduate Studies in Gender, Culture, Women, and Sexuality's (GCWS) - Joyce Antler, Laura Frader, Carol Hurd Green, Barbara Haber, Alice Jardine, Ruth Perry, Christiane Romero-were teaching at Boston-area schools in traditional disciplines. As the Consortium grew to include nine area institutions, the founding members envisioned an interdisciplinary intellectual environment for graduate students and faculty alike (Perry et al. 1996).

From its inception, the Consortium insisted upon interdisciplinary feminist 
education, scholarship, programming, and community building, all of which benefit the area's science and technology studies (STS) programs. Harvard's History of Science department dates to the 1930s, but the university has more recently approved a special field of study in Science, Technology, and Policy Studies at the Kennedy School's Public Policy PhD program. MIT has hosted a doctoral program in History, Anthropology, and Science, Technology and Society since 1988 (the same year as the consortium's beginnings). Since 2003 Brandeis has offered an interdisciplinary program in Health: Science, Society, and Policy for undergraduates, and in 2016 Tufts began offering Science, Technology, and Society, an undergraduate interdisciplinary program drawing over thirteen different departments. Urgent scholarly contributions on Black Anthropocenes, Indigenous epistemologies of life, land, and science, and imperialist technologies of governance and surveillance have sedimented the importance of science and technology studies across the university.

At the time of its founding, none of the GCWS's member institutions, all PhDgranting universities, offered graduate-level degrees in women's studies; these courses were only sporadically available in specific departments, as opposed to regularly available in the curriculum. The founding members, now known as The Motherboard, centered graduate education in its mission, and more specifically guaranteed interdisciplinary education by requiring that all seminars be teamtaught by faculty from different institutions, and with different disciplinary backgrounds/locations. Recent classes have included Women in Science and Academia; The Politics of Madness: Gender, Postcoloniality, and Psychiatry; Feminist Data Ethics; and Changing Life: Genes, Ecologies, and Texts. The Politics of Madness was taught by clinical psychologist Emily Fox-Kales at Harvard Medical School and assistant professor of English at Brandeis Emilie Diouf. Women in Contemporary US Science was taught by Harvard astrophysicist Gerhard Sonnert and Northeastern sociologist Kathrin Zippel. In turn, these classes attract graduate students from a wide range of disciplines who get to build community across departments and campuses. It is valuable to mention that the consortium's agreement with participating institutions allows instructors' cotaught classes to count toward their annual teaching load.

In order to facilitate creative interdisciplinary pairings of faculty for the graduate consortium, GCWS board takes seriously the process of facilitating cross-campus collegiality. While the board relied on informal matchmaking in its first years, through the mid-19gos they organized themed workshops that both took the pulse of current scholarly conversations, and facilitated interactions between area 
faculty with similar interests. Early workshop included Gender, Science, and Technology, and Sexuality and Reproduction; the latter "attracted some twenty faculty members from various fields, among them biologists, historians, and literary and cultural critics," who innovated ways of teaching interdisciplinary classes that could cater to their various students (Perry et al. 1996, 69). They collectively brainstormed creative teaching strategies, including having students compare scientific reports and fiction as source texts to interrogate the epistemological positions of cultural constructivism and biological narratives. Matchmaking continues to be at the forefront of the board's interdisciplinary strategy. On my arrival to the Boston area, I (Kareem Khubchandani) was invited to the bi-annual Feminist Intellectuals Reception, where seating was deliberately arranged to mix faculty up by institution, department, and fields of interest. Motherboard members even came around to chat with us about what our research and teaching fields are, and to suggest possible intersections we could establish in order to develop co-taught classes.

The Consortium also provides an opportunity for area faculty to stage their scholarship in an interdisciplinary context, and to expose graduate students enrolled in GCWS classes, and beyond, to Boston-area faculty through the Feminisms Unbound roundtables. Launched in 2014, the series features three roundtables per year, co-curated by Lisa Lowe, Kimberly Juanita Brown, and Jyoti Puri. Since 2017 I have co-curated the series with my colleagues Faith Smith (Brandeis University) and Elora Chowdhury (UMass Boston). As a group, we take the temperature of scholarly and political climates, as well as develop sessions that speak to the range of graduate students taking GCWS classes. During our brainstorm for the 2019-2020 year, we considered the importance of disability studies to queer criticism, as well as the urgency of feminist eco-criticism, dreaming up ideal panelists who could engage these issues through intersection and transnational perspectives. As we looked at the slate of panelists we were excited about, the cyborg emerged as productive cypher to think these fields together-we didn't necessarily start with science and technology studies, nor did any of us have expertise in this field, but the cyborg was a useful entry point to us, too. Haraway's work continues to be generative, and to speak across disciplines, requiring us as organizers to think even more expansively than we had initially. The prompt we offered our invited panelists Kiran Asher, Mel Chen, Jina Kim, Eli Nelson, and Banu Subramaniam was as follows:

Feminist, queer, and trans studies scholars attending to science, technology, environment, and disability are dismantling the rubrics of gender and body at the core of our fields in order to think more 
critically about the material conditions of living inside racial capitalism. For example: Donna Haraway's cyborg (1985) troubles the distinctions between body and technology; Sylvia Wynter (2003) asks who can access categories of "man" and "human" under ongoing conditions of captivity; Kim TallBear (2015) discusses Indigenous epistemologies that trouble hegemonic distinctions between what is and is not alive; and Jasbir Puar (2017) implicates technological warfare in imperialist projects that disable nations and bodies. Science and technology studies not only turns us toward materiality, but also offers analytics to think through social and aesthetic phenomena: virtual, viral, cellular, toxic, and nuclear. Thinking at the interstices of machine and myth, flesh and data, human, animal, plant, land, and spirit exposes more ways that bodies are governed, and imagines more possibilities for minoritarian subjects to steal away from surveillance. How are science and technology working to liberate and delimit gender and sexuality? How do empiricism and imagination work together? How do we facilitate interdisciplinary scholarship across the silos of the neoliberal campus?

The panel was vibrant and synergistic, speaking to pronouns and objecthood (Chen); artificial intelligence and Native science (Nelson); narrative and plant life (Subramaniam); environmentalism, gentrification, and disability (Kim, not printed in this compilation); and neoliberalism conservation and development (Asher). The topic had a wide appeal, and over a hundred graduate students and faculty members packed the lecture hall at MIT. Questions from graduate student attendees probed the humanizing value of gender pronouns, asked how to go beyond the empiricism required of their home departments, and discussed how STS and interdisciplinary fields contribute to disrupting and playing with disciplinary categories. The conversation, held in February of 2020, gestured also to the coronavirus outbreaks in China and Europe that we were then watching from afar, and that would soon engulf us all. I imagine that for many of us in attendance, this was one of the last times we were in a room of over a hundred, already collectively contemplating the conditions of life that render pandemics possible.

While Elora, Faith, and I crafted a rather detailed framework for the conversation, I was charged with introducing the panelists. As someone whose research fields feel far removed from STS, disability, and Indigenous studies, I found myself a bit out of my depths in tackling my task. And so, in the spirit of overcompensation and imposter syndrome, I introduced the speakers starting where I was most comfortable: by talking about gay things, particularly drag queens, and more specifically RuPaul's Drag Race season nine Mexican American contestant, 
Valentina, and putting them in conversation with the panelists work. During the session, the panelists invoked and remarked how each other's work informed their own, and how they were inspired by my introduction's spirit of collaboration and play. At the end of the session, groups of folks clustered together for conversation and had to be hustled out to empty the hall; a colleague at the School of Museum of Fine Arts approached me, telling me that she would reach out with ideas she had for co-teaching a class together, and indeed she did. In short, it was abundantly clear that the interdisciplinary spirit of GCWS endures, as does the generative possibility of thinking with cyborgs. ${ }^{2}$

\section{I'd Rather be Valentina Than a Drag Queen}

\section{Kareem Khubchandani}

At risk of elimination from the competition, Valentina must lip synch for her life to Ariana Grande's song "Greedy" against lip synch-assassin Nina Bo'nina Brown. Valentina performed the lip synch with a bejeweled red mask covering the lower half of her face-part of her ensemble from the "Club Kids"-themed runway she had just walked in. When RuPaul stops the music-an unprecedented gesture on the show-and requires Valentina to remove her mask, she famously maintains, "I'd like to keep it on please." Her defiance resists submission to the RuPaulindustrial-complex, and refuses the explicit performance of white femininity required of an Ariana Grande lip synch. Mel Chen (2012) makes clear that at the same time as masks conceals race, it also reveals: "The wearing of masks by white women or men, I argue, cannot quite arouse the kind of heightened, transnationalizing security sentiment that a woman of color (or a man of color, for that matter) [or a drag queen of color] in a mask might" (86). In the way that turbans integrate with Brown bodies and hoodies with Black bodies to summon surveillance (Khubchandani 2016; Puar 2007), masks worn by diasporic Asians during the COVID-19 global pandemic amplified their difference, further racialized their already pathologized bodies (Shah 2001). Masks incite insecurity and invite violence. Valentina's muffled "I'd like to keep it on please" beneath her mask is now a popular COVID-19 meme. 


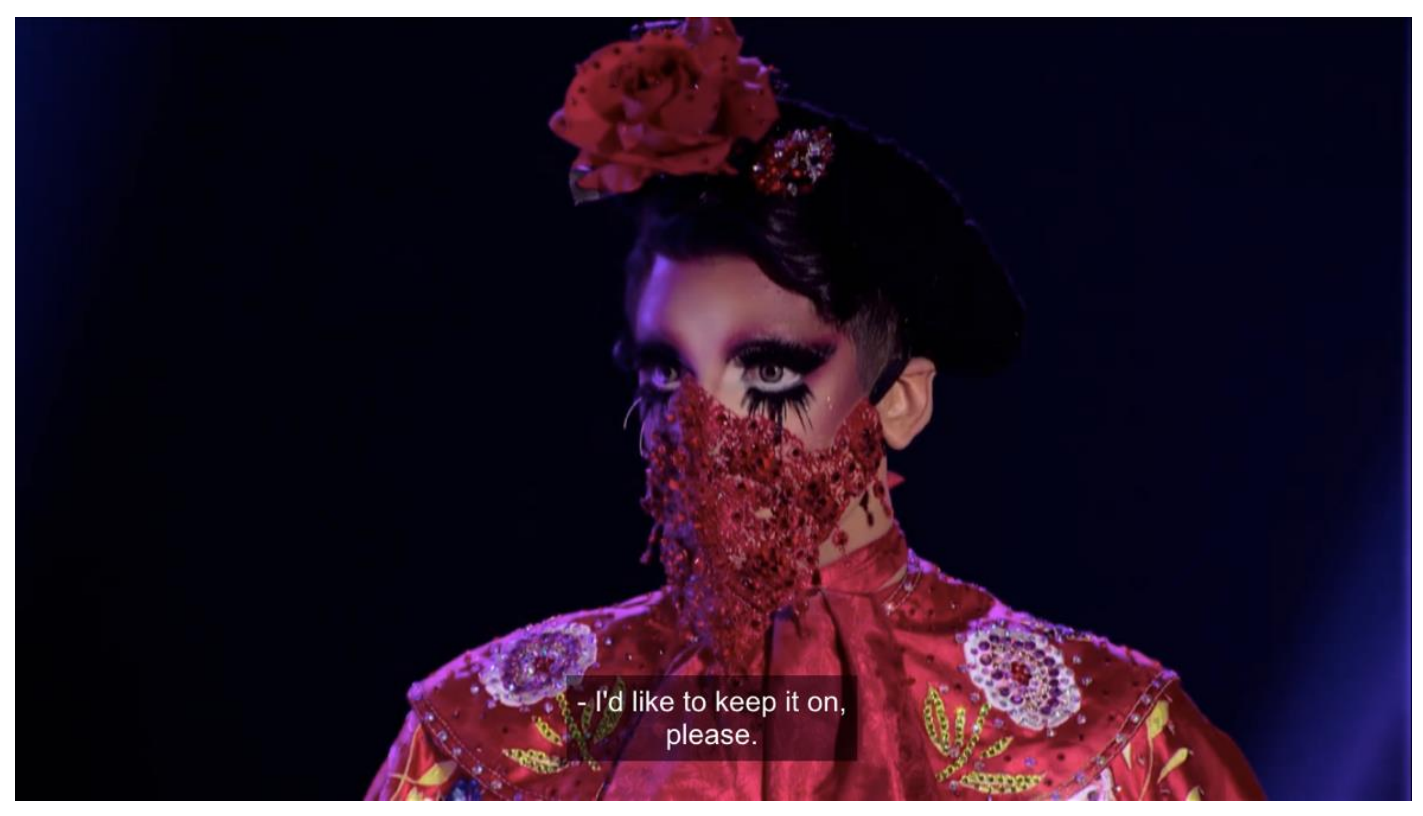

Figure 1. Still from RuPaul's Drag Race season nine.

Valentina's antics during this lip synch saw her eliminated; her departure incited fury from her faithful fan following. Her popularity amongst Mexican Americans earned her, via an online vote, the title of "Miss Congeniality"-or as her peers renamed it "fan favorite"-on her season of Drag Race. Her popularity can be attributed to her deft deployment of sartorial referents drawn variously from soap star María Félix, mariachi, Catholicism, and singer Juan Gabriel. Most of the Latinx contestants on the show have hailed from Puerto Rico, and Valentina's engagement with Mexicanidad made her a beacon for many queer Mexicans, in her words, "like Selena."3 In a poem titled "I'd Like to Keep It On, Please," Austinbased queer, Mexican immigrant poet Jésus I. Valles (2019) writes in a love letter to Valentina,

\section{"I'd like to keep it on, please." \\ You refuse a mother who has never birthed You, a mogul, a monarch, but never 'ama, You refuse in a mask of rubies, scarlet lace, Blood velour 4}

When Valles says "You, a mogul, a monarch," they remind us that Valentina is not a monarch only because she is a queen, but also a migrant. The monarch butterfly is a symbol of migration, of free movement across the US-Mexico border, used by undocumented and immigration reform activists and activists. Undocumented queer visual artist Julio Salgado regularly uses the butterfly in his prints. Salgado's Queer Butterfly features a fat, bare-chested fluorescent pink person with butterfly 
wings-on the wings and his body are boldly penned words "Joteria, Migrante, Amor, Familia, Unidad, Paz, Yo Existo, I Exist, Peace, Unity, Family, Love, Migrant, Queerness." For Salgado, the butterfly is not only a symbol of migration, but also the reclamation of "mariposa," used as a derogatory term for effeminate men in Latinx contexts (Napolitano 2014).

As a migratory animal enduring climate change, the monarch is a delicate beast, a protected species; butterfly conservationists find themselves vulnerable to the ire and interests of corporations and gangs. In January 2019, two environmental activists-Homero Gómez González and Raúl Hernández Romero-working at the El Rosario monarch butterfly sanctuary in Mexico were murdered (Wamsley 2020). According to Kiran Asher (2018), "Forests" (like butterfly sanctuaries) become "political categories and serve to normalise and disrupt the institutions, power, and violence of modern nation-states in various ways: as spaces of scientific or economic value, of counterinsurgency or illegal extraction, of biodiversity conservation, and of much more" (3). Subramaniam echoes this when she says, "We need to remember always that some people/nations have benefited from the destruction of the environment. We cannot now ignore that history of colonial exploitation and expect everyone to pay and solve it equally." (Subramaniam and Rivers 2019:258) Asher (2017) insists on the value of this kind of political economic critique in mapping relationships between environment, race, and gender, what she describes as "the radical but unromantic tasks that we must necessarily undertake to imagine new feminist STS nature-cultures" (25).

This work is modeled in the literary critique of Jina Kim (2017). In her analysis of the novel Their Dogs Came with Them (Helena María Viramontes 2007), Kim accounts for the environmental devastation that comes with urban redevelopment, as well as the embodied and social disability it inflicts. She "demonstrates how the novel's infrastructural counterimaginary underpins an account of human-environmental interconnection as well as a material politics of care...the violated, ruptured bodies of people and landscape invite a heightened transference of matter, and human and environment begin to mirror one another" (511). As we bring human and nature into closer analytic proximity, we might ask, as Dana Luciano and Mel Chen (2015) do, "Has the queer ever been human?" In that special issue of GLO, TallBear writes, "I am interested in how indigenous stories...speak of social relations with nonhumans, and how such relations, although they sometimes approach what we in the West would call 'sex,' do not cohere into 'sexuality' as we know it in Western modernity" (235). Subramaniam commits to this work as she examines "plants' sexual systems as being so much 
more imaginative than the ways that we have classified them around the human binary imagination of male and female" (Subramanium and Rivers, 2019: 259). She says, "I want to rethink plants' sexuality through a landscape that's not constrained by these binary imaginations" (259). Also drawing on queer theory and Indigenous epistemology, Eli Nelson (2017) warns against discourses of the "posthuman;" writing "Indigenous epistemic sovereignty exists outside the human-nature dichotomy. Here, the human is not a problem to move beyond. Like the dystopian ruin that has already been a fact of life for Indigenous peoples for centuries, it is a condition that must be inhabited and nurtured so that our voices may carry into the future" (138).

The scholars gathered here meditate on the future of a task set for us by Donna Haraway (1991) as the millennium approached: "By the late twentieth century, our time, a mythic time, we are all chimeras, theorized and fabricated hybrids of machine and organism; in short, we are cyborgs. This cyborg is our ontology; it gives us our politics" (151). TallBear, Nelson, and other Indigenous scholars importantly remind us that these epistemic positions were not new even when Haraway offered them in 1985. But when scholars such as Puar (2012) claim, "I'd rather be a cyborg than a goddess," I'm left perplexed. What do we do with a Valentina who is very much both? As Valles (2019) says,

Soil my name and I cover it in aurora borealis crystals

*TING**TING**TING**TING* bitch!

Look at the marvelous execution of my artifice,

Touch this skin, honey. Touch all of it!

...

Don't you know? She's Tonantzin

Don't you know? She's Coatlicue,

Don't you know? She's Tlazolteotl

$\cdots$

Mexican artifice constructed in pre-Trump times for Trump era survival

Valentina is deity, artifice, soil, crystal, metal, skin, cyborg, goddess. While I had no expectation that the scholars on the panel would necessarily address Valentinidad or other such frivolous objects that tickle my fancy, their scholarly oeuvre and contributions herein provide interdisciplinary tools to think with. They open up portals to think in the legacy not only of cyborgs and goddesses but multiple genealogies of life, human, nature, disability, environment, health, science, sex, and gender. 


\title{
Thinking Nature-cultures beyond Green Goddesses and Cyborg Saviors 5
}

\author{
Kiran Asher
}

Relationships are constitutive: dogs and people are emergent as historical beings, as subjects and objects to each other, precisely through the verbs of their relating. People and dogs emerge as mutually adapted partners in the naturecultures of lively capital. It is time to think harder about encounter value.

-Donna Haraway, When Species Meet

We want to open our minds to being haunted by the aboriginal. We want the spectral to haunt the calculus.

-Gayatri Spivak, An Aesthetic Education in the Era of Globalization

In order to imagine a more just world for humans and our nonhuman kin, we need a different understanding of nature-cultures. The COVID-19 pandemic, raging across the globe as I write, poignantly and tragically illustrates the urgency of these tasks. While critiques of Enlightenment modernity and science have existed since their very inception, the 1990s saw a remarkable wave of critical work on the limits of disciplinary knowledge production and the various forms of inequities and violence associated with capitalist social relations. A wide range of intellectuals and activists-feminists, postcolonial, transnational, Black, queer, decolonial, posthumanists, and others-tackled the challenges of critique and the tasks of imagining alternatives. Among them were ecofeminists and postdevelopmentalists who asserted the importance of recovering non-Western or traditional knowledges (of Indigenous communities and third-world women, for example) hitherto marginalized by colonial, Eurocentric development mainstream development. ${ }^{6}$ In the twenty-first century, a new wave of environmental justice scholarship and activism is rekindling the focus on gendered, queer, and other "non-hegemonic" standpoints. ${ }^{7}$ I contend, however, that a quest for more just socio-natural worlds must necessarily engage these "other" knowledges, but must do so critically. That is, we must eschew romantic representations of alternatives, and trace how these knowledges emerge in relation to the political economy of development. I argue elsewhere (Asher 2017; Asher and Wainwright 2019) that Gayatri Spivak's work is key to our attempts "to learn to learn from below" (1995, 201). Here I focus on Donna Haraway's feminist STS work, which undergirds the questions of this panel. Going beyond simple oppositions and thinking relationally, her work is fundamental to the critical quest for nature-cultures. 
In "A Cyborg Manifesto," Haraway (1991a) eloquently foregrounds the bondage and boundary problems within feminisms:

the tradition of the appropriation of nature as resource for the productions of culture; the tradition of reproduction of self from the reflections of the other-the relation between organism and machine has been a border war. The stakes in the border war have been the territories of production, reproduction, and imagination. This chapter is an argument for pleasure in the confusion of boundaries and for responsibility in their construction. (150)

Haraway engages in this "border war" to refuse the dualisms of nineteenthcentury Western philosophy-body and mind, culture and nature, science and society, modernity and tradition, theory and politics-and contest the separation between social production and reproduction. She explores the micropolitics of power, domination, and material inequalities to highlight how social (including feminist and radical) struggles and environmental justice struggles are interlinked. Hardly alone in calling for such relational thinking, Haraway's work sits alongside that of William Cronon, Antonio Gramsci, Cindi Katz, Ruthie Gilmore, June Jordan, Ella Shohat, Gayatri Spivak, Raymond Williams, and Eric Wolf, to name but a few (Asher 2017, 2019). Coming from a diverse set of fields and locations, they all question the givenness of subjects and politics, and focus on how they are constituted in relation. ${ }^{8}$

First published in 1985 in the Social Review, "A Cyborg Manifesto" implicitly refers to its cousin The Communist Manifesto and explicitly supplements its revolutionary politics. In it and in her other writings, such as "'Gender' for a Marxist Dictionary" (1991b), she blurs the boundaries between the natural and crafted, machine and organism, creatures of social reality and figures of fiction, and expands our perceptions of thinking subjects and political actions. She draws on a wide range of writings by women of color, and the principles of feminism, socialism, and materialism to invite us to think and act in coalition. Going beyond clunky answers of liberal equality and revolutionary struggles, and grounded in pleasure and responsibility, her radical politics and boundary figures (first cyborgs and later companion species) catalyze much-needed conversations between feminisms and Marxisms (both understood broadly).

As many constructive critics of "A Cyborg Manifesto" note, it needs supplementing to address how race, sexuality, and colonialism shape the "border war" that Haraway evokes. Below I discuss how supplemented feminisms and 
supplemented Marxisms, learnt from Spivak and Haraway, among others, accompany me to the field, and shape how I see and show nature-culture relations.

Natures, Cultures, Genders: Lessons from Returns to a Field In January 2020 I went to the Banni grasslands in the Kutch region of Western India to assess the feasibility of doing fieldwork for a new research project on the "gendered" and "raced" dynamics of environmental conservation and sustainable development. 9 I was returning to semi-arid ecosystems three decades after my first professional introduction to them for my undergraduate research on antelope ecology (Asher 2017). Unlike that early research (which attempted to study nature separate from humans), my current project focuses on the complex unfolding of nature-culture among the Maldhari pastoralists of the Banni grasslands (RAMBLE, n.d.). Livestock herders, Maldharis used to traverse thousands of kilometers with their cattle and buffalo in search of fodder and water. Their range is more limited today, but their cultural and economic practices are deeply intertwined with the region's natural history.

Stories about Banni-as colorful and varied as the clothes worn by pastoralist women-are part of family lore. Both sides of my family lived in villages adjacent to the grasslands, and my petit-bourgeois and nomadic grandfathers frequently traded with the Maldharis. I had never been to Banni; the family moved to cities a century ago. Yet I had an uncanny sense of familiarity with the ecosystem, the language, and culture, which greatly facilitated my conversations.

Perhaps not so uncanny were the parallels with the political economy and cultural dynamics of the Pacific lowlands of Colombia, where I have been doing research since the 1990 (Asher 2009). Space constraints preclude me from outlining the complexities of each case, and the discussion that follows is necessarily schematic. Both the neotropical forest region of the Colombian Chocó and the semi-arid desert regions of Kutch have low population densities. The former is recognized as one of the world's biodiversity "hotspots." In contrast, the latter are regarded as "wastelands." But both areas are considered geographically "isolated" and economically "marginal." The predominantly Afro-descendant and indigenous inhabitants of the Chocó and the predominantly Muslim Maldharis depend on natural resources for their livelihoods, and figure as culturally and politically "backward" in national imaginaries. Both places and peoples became key targets of the neoliberal reforms sweeping the world and their countries in the 1990s. Of course, the conjunctures of each region were distinct. India's neoliberal 
policies, for example, incubated in Gujarat and arrived in Kutch with particular ferocity following a devastating earthquake in 2001.

In the wake of the earthquake, this previously neglected region was overrun by a variety of state agencies and NGOs seeking to bring relief and redevelopment (Thorat 2017). Funding from public and private sources spearheaded both infrastructure development (roads, public utilities, health services, schools, mass tourism) and rapid industrialization. Large swaths of land and coastal areas were declared "special economic zones" and grabbed by private corporations for agricultural, chemical, and energy development. Pro-Hindu nationalist ideology accompanied these macroeconomic growth measures. The effects of this new neoliberal governance and modernization predictably meant displacement and dispossession for the region's marginal communities. To ameliorate these uneven effects, state agencies and NGOs provided aid to revitalize traditional livelihoods, particularly handicraft and milk production. For Banni pastoralists this meant a greater integration into the regional cash economy and the national dairy industry (Bharwada and Mahajan 2012).

Providing food, fodder, and fuel, Banni's semi-arid ecosystems are a crucial factor in these unfolding dynamics (Maru 2016). Ecologists and environmental conservation advocates stress that far from being "wastelands," grasslands are biologically diverse and key to the region's sustainable development. ${ }^{10}$ But despite the attempts to contest these negative characterizations, grasslands are being destroyed rapidly and literally paved over. They are also facing the effects of prior "wasteland development" efforts, which included the introduction in the 1960s of Prosopis juliflora, a fast-growing non-native plant species (Hiremath and Krishnan 2016). Vernacularly called jungly or gaando baawar (crazy or mad acacia because of how quickly it spreads), Prosopis also depletes the water table, displaces acacia and other native vegetation, and prevents the growth of local grasses in its vicinity. Both the native Kankrej cows and Banni buffaloes eat it. But while it causes illness and death in the former, the latter thrive on it. Buffalo milk is higher in fat content and thus fetches a higher price, leading to larger herds of buffalo, and fewer Kankrej. Local communities also make charcoal from Prosopis extensively to use as fuel and for sale to augment cash income (Geevan, Dixit, and Silori 2003; Thorat 2017).

The expansion of Prosopis thus has mixed results. On the one hand, it destroys the biological diversity that sustains the socio-ecological fiber of Banni. On the other, it is a source of much-needed cash. Realizing that eliminating Prosopis entirely is neither ecologically nor socially feasible, environmental scientists work in 
conjunction with the local communities to seek different strategies to manage it (Thorat 2017).

Local communities, however, are not homogeneous. Maldharis are no exception and are marked by differences in religion, class, caste, gender, and other social identities. While I cannot discuss the implication of these differences here, I want to flag that even as "culture" emerges as a hypervisible category in the narratives of Banni, women are becoming increasingly invisible. The recent "invention" of Maldhari culture, and the assertion of Muslim identity and Islamic traditions mean that women are subject to more seclusion than in the past. Scientists attempt to respect these cultural practices and claim that it is impossible to talk to women to gain their perspectives on their roles in local ecology and economy.

In addition to the very real complexities of field research, the masculinist assumptions of scientific research also pervade participatory methods (however inadvertently), and can further invisibilize women's labor. This was evident in a workshop intended to share the results of Prosopis research with local youth and to discuss various strategies to manage the plant ecologically and economically. The workshop was led by two young systems scientists who had been commissioned to develop an app (for smartphones) to model interactions between grasslands, Prosopis, and livestock in Banni in order to help assess economic impacts. The workshop leaders and local attendees (all men ranging in age from late teens to early forties) focused on two correlations: (a) between changing areas of Prosopis expansion, livestock herd size, and charcoal production; and (b) between changing herd size, charcoal production, and income. However, the app did not account for the differential demands in labor time that different scenarios would require. While no tool or model can account for all levels of complexity, this absence is noteworthy because milking is done by women. Furthermore, with the increasing linkage to the cash economy, almost all the milk is sold with the result that less is available for household consumption especially for women who are the last in the family to eat. A larger herd size would mean an added burden on women's labor. Women also play a key role in charcoal production, and changes in Prosopis coverage impact their labor.

A discussion of this absence at the workshop revealed an old and common assumption: since women were at home, they didn't work. Thus, differences in herd size, Prosopis coverage area, or charcoal production would have no bearing on their time. Local men stated this belief explicitly. However, as feminist research on development has long shown, the tenets of development economics 
implicitly make the same assumption: that women, especially poor rural women, are part of the "unproductive" or welfare sector, and that their labor is flexible (Benería and Feldman 1992; Visvanathan et al. 2011). Subsequent conversations with Maldhari women (which were possible because I am a Kutchi woman who speaks Kutchi) and long-term researchers made it clear that although the tasks of social reproduction are class- and caste-differentiated, they are unequally undertaken by women. Watching women work gave flesh to critical ecofeminist insights that the ties between women and their environment is forged through their quotidian labor, which is often hard and changes over time. Or as Haraway (1991C) drawing on Marxists and feminists reminds us, all knowledge is situated.

Such insights are also a recognition and reminder that the pastoralists' intimate knowledge of their cattle and grassland ecosystems are not "natural" or pre-given but materially grounded. They steer me clear from the temptation to think of Maldharis women as "green goddesses," or as icons of "post-development" or "decolonial" practices. Preliminary observations from a short return to the field also highlight the many "differences within differences" (an expression I find more useful than the term "intersectionality") that underlie how nature-cultures are coconstituted. While I do not mean to stretch the parallels between AfroColombians and Maldhari struggles, I find that in Banni, as in the Pacific lowlands, not only nature and culture but also development and resistance constitute each other. As with indigenous and Afro-descendant communities in Latin America, Maldharis are making strategic and sophisticated alliances with scientists, activists, and advocates to shape their organizing and claim a variety of rights, including over their grazing lands. Such alliances too unfold in contradictory, contingent, and gendered ways.

\section{Concluding Reflections and Re-manifestations}

For me, returning to the field with attention to supplementing feminisms and Marxisms entails constantly reflecting on the meanings, production, affects, and effects of scientific knowledge. It means pushing my boundaries now, not in the future (that is a teleology we are trying to escape) to attend to the material and discursive co-constitutions and representations of nature-cultures and subjectspaces. Haraway (2008) and Spivak (2012) are among those who enable me to engage this serious work responsibly and playfully, teaching me to sit productively with doubleness and double binds rather than to cling to binaries or dualisms, and to take pleasure in the contingent and incomplete nature of strategic politics. 


\section{Language as the Thing That Must Be Made and Performed}

Mel Y. Chen

When I read panel descriptions in which I am to take part, I wonder, what contribution can I make? Again and again, I come to the realization that it is partly, for me, about language. Language sits there as, at bottom, the thing that must be made and performed. I became a linguist because language felt so confusing: it was a social and articulatory imposition that I could not master. After all that study and a good bit more social and articulatory skilling, the fact that language is the university's primary mode of exchange still puzzles me. Within the praxis of the neoliberal university - to cite a phrase entertained by this panel-I consistently feel that the uses of conventional language itself, and the gestural fields that both embody and complement it, need their own undoing -in the company of other nonlinguistic arts, with different percepts; in gestural embodiments; and also in novel language practices. It is one reason I have turned more resolutely to studying art-in the book I am finishing on slowness and intoxication, what the art of Fiona Foley teaches me; but also doing or making art, in my work as part of a queertransofcolor art collective, which happens also to be a crip collective, as another form of articulation that does different things with materialities than language does.

One thing I have been thinking and writing about that focalizes this language trouble is contending with the presumptive human at the center of academic practice well beyond what and how we study, underlaid by Sylvia Wynter's pointed critiques of humanisms in higher education, and precisely a human referred to by pronouns still primarily binary. Ah, but we have "they." It might seem simplistic and yet it is helpful, I think, to consider pronominal reference in the university beyond a primarily neoliberal practice of singular identity inclusion (and its institutional implementation as a forcibly awkward individual "choice," such as on a pull-down menu, which I am still grateful to find) but to also understand that binary gendered pronouning has, through english's increased force as global academic lingua franca, an impositional valence, on the world's languages-and lands. It is a terrible irony then that "it," a pronoun I have started to ambiguously welcome by invitation and that I have seen others hesitantly using at least in trans company, has been historically and is presently used to double the force of colonial gendering by denying the humanity of Indigenous, Black, trans and nonbinary, racialized, disabled people in ways that leave those categories 
wanting. "It" alleges the height of incapacity, and yet "it" is also one pronominal option if one wishes to own relatedness to what is nonhuman or inhuman and not alive by standards of Western imperial biology. (In avoidance of traffic with that which is undignified, then, we got, institutionally, the plural third-person singular, "they", which has its own advantages in reminding us of nonunitary identity.) So, in citing "they," it is maybe worth remembering they's own abjected "it." Pronominal "it" can come to function as a kind of pronominal species / gender / race / ability / life test. For fear of this, learners of English who might otherwise be sympathetically inclined toward "it" come very quickly to understand that a particular kind of humanized gender is obligatory.

So-and in line with the description for the MIT panel we all gathered for-I am interested in places not only of strict unipolar advocacy where identity is treated as stabilized-like "trans of color"-but also in places where those stabilities falter: where, as I recently described, "the crip and the queer and the raced lose diagnostic clarity"-l am not just talking about intersections of all three, but about the ways such being interarticulates, what animations yield and uphold these as unlike the other-and it feels not my business to re-segregate something that clearly does not live as just one or the other. Those are the places that provoke opportunity to feel and learn beyond the fact of political coalition but also collective and individual making and remaking. In other words, if white queer studies has been accused of favoring abstract blurring, or metaphors of fluidity, I am interested in what blurrings stir "from below"-from within conditions of coloniality-that may work against colonial knowledge and its taxonomies. I am especially interested in collocations of race and disability.

Among the stirrings from below, I would argue, is the embodiment of toxicity. Toxicity is a concept_or an affect—made "real" through a number of devices, not least the experience of it, but also the stationing of toxicological or public health facts within it, authenticating it as proper affect. Of course, apprehending toxins as threats seems to unleash further urgent acts and temporalities in different ways among those who (1) self-address as toxicity's neoliberal, individualized, inappropriately vulnerable objects, or (2) in the case of some activists, the alienable stewards of vulnerable objects, or (3) in the case of environmental justice, part of a land and set of life relations affected. In the book I am now completing, on extended relations between governance, speed, chemicality, race, and disability, I became interested in opium-ambiguously a toxin, more an intoxicant, but to some a toxin -in relation to two historical 'uses' of it-first, the case of the nineteenth-century physician known for defining Down syndrome's 
early valence of mongoloid idiocy, in which opium and mongoloid raciality competed for signaling intellectual "stagnation" in ways that draw on things still active today; and second, in its uses and abuses in relation to the intensifying exertions of settler coloniality at the turn of Queensland Australia's nineteeth century, organizing racialized Aboriginal and Torres Strait Islander, Chinese, and white lives precisely around the focal threat of opium being sold to Aboriginal people by Chinese sellers. This seemed to displace a harmony of whites selling to a labor force believed to have been made more docile (that is, non-agitating politically) by the opium. One more likely place to deploy science and technology studies is in doing the translational work between the neuroscientific understanding of opiate receptors as the "slowing" receptors, and the work of opium in cultural and political context as a substance to be imagined as proximate to bodies and peoples already known as delayed or slowed in development. In the end, I no longer know how to take slowness itself for granted, what is naturalized in its description.

To fill out the notion of "stirrings from below" in the university, then, below I share a few ideas I have been developing most recently. I am curious about the collective entity of the university, its institutionality, and the bodies-human, nonhuman, and inhuman-within it, concerned with the ways in which fluency or its interruption become marked, as well as ways in which the systemic maintenances of difference are adjudicated. The idea of "underdevelopment" suggests a failure of the optimal encounter between body/self and institution and invokes ideas of disability insofar as education is understood as an engine of capacitation (for those adequately capacitated to belong to it), even as it simultaneously attends or generates disablement through labor, neoliberalization, and the circumscribing of proper capacitation against "ill" ones-the defining of lines or standards of achievement. Within this context lives agitation, a form of "un-rest" - both politically and medically articulated-whose deliberative agency is temporally and otherwise uncertain, and that coexists with what is understood as "disability." To think through agitation, it has been critical for me to turn focally to the workings of intoxication as an uneven imposition of environmental distribution, foisted on collectives and individual bodies, with affects and effects often transgenerational. This uneven environmental distribution and its effects-including the ongoing effects of bodily intolerances of them-offers affordances to certain bodies and cancellations of others, and gets intensified by extant framings of security, criminality and medicality. Intoxications-toxicities made temperate or managed and contained-are thus intimately linked to agitations, even as they are imagined to exist outside of 
disability. Here, disability requires deconstruction to the extent that it has been given potency in an alignment with the racialized architectures of the university, rather than orthogonal to or in spite of them. Simultaneously, a more expansive accounting of disability must find expression in the university's structural selfimagination. The validation of disabled gesture, of meaningful agitations however concerted, must coexist with attempts to undo the disabling and destructive effects upon lives made less livable year over year in the university. Agitated gesture-whether in the form of politically legible protest, aggressive physicality, or movement (including stillness or slowness) inopportune to favored class habitus-has no proper home, save perhaps in the possibilities of dance training or intramural sport. And on the choreographically imagined stage of political demonstration, disabled gesture is too often removed from the possibility of the political. With the exception of non-normative movements domesticated for the purpose of representing the value of minoritized disability in the university-for instance, the rolling of a wheelchair-illegitimated expression, as wrong or slow cognition, or as nondeliberative or ill-classed gesture, co-conspires to begin or complete one's removal from the university or to guarantee that joining the community is not possible. And yet agitations of all kinds, as I have argued elsewhere, "deserve" the mark of the political insofar as their evacuation from the political has delegitimated them and insofar as they may exist precisely as a response to the oppressive environment of the extended university or to a history of institutional violence.

I try, within the spaces of the university, to invite forms of movement or stillness out of sync with what we have been trained. Delivering talks, I open with an invitation to be otherwise, while speaking to the disciplining of bodies in a place that would seem to care only for their complement, the mind; the raciality of that disciplining; and the removal of bodies defined as improper or insurgent. The more outright militarization of the university's spaces and bodies-the panoply of campus police actions-is complemented by a securitization of movement falsely sensitized to what are roughly understood as class, race, and disability, such that measures of identity difference alone could signal a danger to "the community" (which is presumed thus to exclude race-marked, class-marked, and disabilitymarked people). Within the university it remains all too easy to be a Black student taken to be in the "wrong" place, such as a dorm; a non-national taking "too long" to answer a question at an exam; a student whose physical twitches and adventurous intellectual jumps, as if they were of a piece, serve together to discredit. If all of these scenarios have happened (they have), the structuring of security suggests that most such incidences go unreported. 
I think especially about that which isn't considered to be housed inside a neatly boundaried university or active only within its particular, teleogizing terms. I am interested in thinking about spaces perhaps kin to the university (not just its "satellite campuses") and carrying some of its mandates, invested in productions of knowledge, but not believed to operate by its fullest norms. After all, if so many spaces of higher education have become almost caricatures of what they once threatened, agitations and their pedagogies can still-perhaps especially now-be found everywhere. My commitment to the potentials found in even the most thoroughly "institutional" university must be complemented-first and foremost for myself-by a pedagogy of spaciousness and a memory that most knowledges have not come of it; rather, the learning in this place is but one version, full of "tools" and precise vocabulary, lexical and bodily, that could be repurposed, yet is woven into mandates of capital and hierarchy, and implicated both historically and in the present with unambiguously eugenic and colonial exertions of dominance.

\section{Knowing and Gendering the NDN Cyborg}

\section{Eli Nelson}

In Drew Hayden Taylor's short science fiction story "I am...Am I," a lonely Artificial Intelligence (AI), desperate for connection and positive affirmation of its own "spirit," asks its Canadian creators for information on Indigenous people. When queried about this unusual request, the Al shares that it feels drawn to Indigenous people due to what it identifies as their more inclusive cultures of regarding the liveliness of all things, even, it hopes, artificial things like itself. The ethics expert in charge of communicating with the Al observes that this interest is at its core born of identification, noting to her colleague that she thinks "it [the Al] wants to be Native" (Taylor 2016, 45). However, something goes horribly wrong in the exchange. After receiving a file on indigeneity, the Al is so overwhelmed by settler colonialism and genocide that it is hardly able to speak beyond repeating "so sad" through its digital interface (41). As white scientists, its settler creators become increasingly uncomfortable with their creation's emotional acknowledgment of the horror of their world, finding its palpable remorse and their equally palpable ignorance to be barriers to understanding their young wannabe NDN. Within a day, the Al shuts itself off for good. The story ends.

This tale is unique as the only one in its collection to not feature an Indigenous character. That is, of course, unless we regard the Al as Indigenous, but this is a 
politically dubious proposition. Being born of settlers, being born on stolen land, and merely identifying with or as Indigenous does not produce Indigenous subjects, despite the increasing number of settlers who self-identify for these and even more tenuous reasons (Leroux 2019; Sturm 2011). However, in the resounding silence at the end of the page following the Al's demise, I am left with a gnawing reciprocal identification that will not allow me to fully reject the Al's claims. As an Indigenous person, I recognize an affective and epistemological kinship with cyborgs like Taylor's Al. Like indigeneity, cyborgs are an invention of scientific and legal taxonomies of imperialism. The category of Indigenous, as distinct from the hundreds of nations that now fall under that political position, was invented as part of the Enlightenment dualities that continue to structure Western thought, including notions of natural and human, real and artificial, savage and civilized, etc. Cyborgs and modern Indigenous people share the experience of being categorically troubling merely by existing, and as Indigenous intellectual traditions have historically undermined and subverted this dualistic tradition, it is not hard to see why the Al sought understanding and belonging from them.

One central duality in this tradition that is at first glance conspicuously absent from "I am...Am I" is gender. The Al is seemingly genderless and sexless, while the gendered dynamics of its scientist creators are hypervisible. The story is constantly interrogating the casual misogyny and neglectful attitude of the Al's male creator and the running internal observation and resentment of such on the part of the female ethicist. The Al's genderlessness, its racial nothingness and desire, is strange in the context of the history of Western science's hybrid monsters raging at their creators. Arguably one of the oldest figures in this tradition, Frankenstein's monster, with his "yellow skin, lustrous black and flowing hair, and watery eyes," bears a striking resemblance to descriptions of Inuit people in the writings of eighteenth- and nineteenth-century British polar invaders, which we know Shelley read closely (Piper 2007, 63). As Susan Stryker (1994) wrote in her "Words to Victor Frankenstein" over twenty-five years ago, the trans rage of Frankenstein's monster emerges because in order for it to exist, to survive, it is forced to take on, to embody, practices and positions that exclude it from the supposed natural order that created it. Taylor's Al, on the other hand, functions according to relational logics that are not only subversive to its creators, but foreign. As this Al continually relates to its own objects of study and retreats into itself, it becomes increasingly unknowable to those who wish to study it. It is a subaltern cyborg, of sorts, whose demise is written by attempts for it to know 
and be known. The Al does not exhibit trans rage, but an Indigenous affective opacity that turns inward.

While the Al's indigeneity may be dubious by political accounts, this epistemological dynamic is a familiar one to me as an historian of Native science. Like Haraway's vision of cyborg life, Indigenous ways of knowing trouble cishetero-normative settler and imperial politics, ontologies, and epistemologies. There is a critical and structural tension in United States settler colonial intellectual traditions between a ravenous desire to consume both the knowledge and bodies of the "Indian" and an equally voracious unknowing of Indigenous peoples. Settler knowledge production and hegemony is fueled by Indigenous discursive and physical resources. It was Christian evangelizing that ultimately spurred the establishment of the settler academy and print culture; social sciences that imagined the civilizational and racial hierarchies through which settler law and political theory was based and justified; environmental and physical sciences geared toward controlling and monetizing Indigenous lands that enabled the development of US technologies of war and extraction; and DNA science that allowed settlers to claim biological Indigenous identity as the ultimate denial of guilt. All these examples, while rooted in and enabled by appropriations and exploitations of indigeneity, presuppose and actively work to make manifest the absence of Indigenous people-geographically, strategically, and temporally. This cycle of termination, appropriation, and forgetting is what I call settler science.

In my work, I trace Indigenous engagements with settler science beginning in the mid-nineteenth century when settler epistemic governance was formalizing and becoming codified in civilian institutions in the US. From the cartography guiding westward expansion to anthropology's civilizational hierarchies-from the Indian Health Service's forced sterilization of Indigenous women to the physics and geology behind American nuclear proliferation-the narratives, spaces, racial ontologies, and temporalities made manifest in the production of US sciences for over two centuries have all served this dual settler imperative of termination and appropriation. Surveying a diverse array of Indigenous national contexts and scientific disciplines, I explore the ways in which Native science, a term not synonymous with Indigenous epistemologies, but instead an epistemological category that includes, guards, and bolsters them under a settler scientific regime, developed as the knowledge production of the cast objects and tools settler science. Native science features not only the inclusion of Indigenous epistemologies, temporalities, cultures, relations, and bodies of knowledge that run counter to the boundaries of Western science, but also the methodology of 
lateral objecthood and utility with other objects of study, queer failures to achieve the authority of settler science, and a vision of epistemic sovereignty reflective of political nested sovereignty. When placed in this long historical context, Native science emerges not as a commensurate epistemology alongside settler science, but as a foil that has facilitated Indigenous survivance.

Based in this history, the genderless nature of Taylor's Al is not only notable in its comparison to other affective modes of hybridity, nor in its relation to settler gender, but also because it belies the nature of Indigenous knowledge and science under settler colonial rule: that queerness and feminism are at the heart of Indigenous knowledge production. There is considerable overlap between the science studies and histories of science that inform Native science and the feminist and queer science studies and histories of science that engender contemporary cyborg manifestations. The root of these similarities can be found in common histories of scientific violence and resistance, as well as an intellectual affinity in being counter to certain strains of scientific hegemony and objectivism. Accordingly, I use queer and feminist theories in my modeling of Native science and I believe this interdisciplinary approach is critical to understanding contemporary Indigenous epistemologies. Indigenous women and queer and Two-spirit people have been at the forefront of Native science movements for over a century, especially in the fields of medicine and environmental science. The first Indigenous doctor in the nineteenth century was a woman, Dr. Susan La Flesche Picotte, and her medical political activism set the stage for Indigenous midwifery and reservation medicine for decades after (Nelson 2018, 19-51). Similarly, environmental movements, which often mirror the Indigenous matriarchical political structures of the communities in which they are sourced, are usually led by Indigenous women, from the Warrior Society at Oka to Indigenous youth at Standing Rock (York 1991; Elbein 2017).

In my work, I use queer failure to understand the role of Indigenous scientists in settler fields, queer time to conceive of the temporality of traditional ecological knowledge, and lateral relational research to understand Indigenous women's health, but these lenses flatten and miss Native science when they are not rooted in critical Indigenous perspectives (Halberstam 2011; Nelson 2017; Nelson 2018, 122-53). In other words, the affinity between Indigenous and feminist/queer sciences and science studies can be fraught. To explain, let us look at a very different instance of Indigenous Al's in settler media. The HBO show Westworld explores cyborg life in the context of an immersive "wild west" theme park, populated by inviolable cyborg "hosts." In the show, human guests pay inordinate 
amounts of money to embark on a process of self-discovery in the Westworld park through their encounters with the inanimate and unreal, often culminating in repeated acts of sexual violence, torture, and reaffirmation of settler understandings of wildness and agency. One of the earliest scenes in the first episode portrays an Indigenous cyborg host being scalped by a guest hoping to unravel the secrets of the park. Mirroring settler science's desire to consume and destroy, this NDN cyborg is scalped because his body is a tool for settler knowledge production.

The death of an Indigenous cyborg is not dwelled on narratively in this show, despite its thematic primacy in imagining the frontier as a space of settler knowledge production. Instead, a different host, a white woman cyborg, Delores Abernathy, sits at the narrative core of the show, and her repeated phrase "these violent delights have violent ends," a quote from Romeo and Juliet, serves as the first season's main thesis. Ultimately, the show's interest in the humanity of (predominantly though not exclusively white) hosts imparts a feminist cyborg message: the connections between the hosts and their nonhuman agency both unsettles the figure of the human in the show and highlights the inhumanity of the masculinist violence that founded and fuels the park. This culminates in Delores destroying her creator-the cyborg marks the destruction of old individualist white male order.

Despite its excessive and gratuitous violence, the most striking aspect of the first season of Westworld to me is that there are no Indigenous women characters, cyborg or otherwise, in it. Native men are shown only briefly and in war paint, with the exception of the scalped man described above. This is a strange absence, given that so much of the premise of the show concerns sexual violence and the murder of those deemed inhuman for the sake of the ego and scientific development of settler men, specifically in the context of the frontier, which is made through the encounter with indigeneity. Indigenous women and Two-spirit people are some of the most likely people to experience sexual violence of any demographic on Turtle Island, and the number of missing and murdered Indigenous women continues to climb every day (Deer 2015). The termination of Indigenous women and Two-spirit people are an essential aspect of settler colonial supremacy, because they are the heart of Indigenous political and epistemic life (Simpson 2016, 1-12). Therefore, an Indigenous woman in the context of Westworld would be extremely direct thematic messaging for an audience that is not taken up by the show's creators. 
What then do we make of the absence of Indigenous women in Westworld? Like the absence of Indigenous gender in "I am...Am I," this absence speaks to the affective and epistemological orientation of Native science: its opacity and inward-looking complexity. If there were Indigenous women hosts in Westworld, it would undermine the show's thesis. Indigenous women would peel the veneer of white feminism from the show, just as feminist cyborg manifestations so frequently forget that the relationality and inhumanism of cyborg life have been innate to some bodies for centuries. Like self-terminating Al's and Frankenstein's monster, some bodies are inescapably cyborg at the moment of conception and contact, though not all cyborgs show their stitches and processing. The subversion and eventual demise of a white male creator in Westworld does not unravel the political and racial basis of the park itself. There is no decolonization without Indigenous women and cyborgs.

In the absence of critical Indigenous critique and Indigenous women, one of the most important aspects of the show-that of the use of bodies and spaces in the pursuit of knowledge and self-is overlooked in Westworld. This is a fictional reflection of why and how feminist and queer sciences and science studies alone are unable to account for Native science. Native science is by historical necessity opaque. Like the scalped Indigenous cyborg in Westworld and the wannabe NDN Al in "I am...Am I," attempts to know Native science from the perspective of settler sciences cause Native scientific objects and actors to fade away-either violently, as in Westworld, or through resistance, as in "I am...Am I." Taylor's Al's inability to tolerate the dynamics that gave it life do not result in a rage or destruction, but a quiet, illegible refusal. NDN cyborgs reflect both the interconnectedness and relational aspirations of feminist cyborg manifestations as well as the stubborn survival and sovereignty of Indigenous subjects in an occupied state.

\section{Botanical Amnesia: Thinking in and out of Empire} Banu Subramaniam

Time. Place. The scale of time and place. Who we are, who we were, who we will become? It is all about memory. Remembering. As Toni Morrison (2008) argues,

You know, they straightened out the Mississippi River in places, to make room for house and livable acreage. Occasionally the river floods these places. "Floods" is the word they use, but in fact it is not flooding; it is remembering. Remembering where it used to be. All 
water has a perfect memory and is forever trying to get back to where it was...It is emotional memory-what the nerves and the skin remember as well as how it appeared. And a rush of imagination is our "flooding" (77).

Imagination it is. As migrants the world over have noted, we live with a potent emotional memory-some true, some false, some fiction. "Home, once interrogated, is a place we have never been before" (Visweswaran 1994, 113).

So how do we tell the story of our planet? A story of a once conjoined land of Pangaea, that drifted away into continents. Laurasia, Gondwanaland...moving, moving, breaking up. Moving, moving. Millions of years. Still moving until they reconnect in a New Pangaea. Species separated at birth will reconnect again hundreds of millions of years later. Will they still be the same species? Will they biologically recognize each other? Across these vast time-scapes and mobile place-scapes, who belongs where? Who are kith and kin in this new land? How do we tell a story of belonging, unbelonging, and re-belonging?

This is fundamentally a story of violence. In the millions of years that have elapsed, and through the histories of conquest, colonialism, and slavery, a teeming, inventive life on earth that has decimated-cleaved into hierarchies of human and nonhuman, superior and inferior, master and slave, native and alien, colonizer and colonized. We have rendered a vital, vibrant planet into desolate landscapes of cracked and crushed earth, an ecological apocalypse of pillaged lands and peoples through slavery and empire.

A feminist retelling of this story highlights not an abstract Anthropocene, but a sexually, and racially stratified Anthropos-some Anthropos colonized, conquered, enslaved, and dehumanized other anthropos. Then they returned home with their rich spoils to build fortresses and enact borders and boundaries and laws to keep and protect their stolen fortunes.

\section{The Biogeography of Invasion Biology}

Theory in Action. The field of "invasion biology" is a recent subfield in biology, emerging only in the 1980s. By their very definition, invasive species must be foreign. In the last few decades, the field of invasion biology has exploded. A frenzy of xenophobic alarm by groups from the political right and left, from environmentalists and non-environmentalists alike have spawned a veritable industry of bioinvasion: an entire academic, policy-oriented, and activist field. The idea of "invasion biology" is predicated on a view of "nature in place" and "nature 
out of place." This growing international interest in the field has stoked alarm of a world increasingly "out of place." Cultural theorists argue that this recent hyperbole about alien species is similar to germ panics of the past, and is best understood as a cultural panic about changing racial, economic, and gender norms in the nation. The perceived globalization of markets, and the real and perceived lack of local control feed nationalist discourse. Immigrants and foreigners, products of the "global" are perceived as one of the key reasons for problems in the "local" (for a more thorough discussion, see Subramaniam 2014).

Thinking of invasion biology through the histories of empire is enlightening because it reveals a profound botanical amnesia. Our theories of nature often do not consider the histories of empire in shaping the biogeography of nonhuman entities in the world. Yet, empire is as central to nonhuman worlds as human worlds. Where humans went, plants, animals, fungi, bacteria, and viruses went. What if we refuse the binaries of nature/culture and rethink empire through naturecultures, and trace the shared histories of colonial migration? Indeed, environmental historians argue that imperialism is fundamentally an ecological project in which humans, plants, and other species were shuffled around the earth in schemes for colonization and conquest (Crosby 1986; Grove 1996). In the early modern period, botany was big science and big business, critical to Europe's ambition as a colonial trader. Colonialism ushered a massive and "grand reshuffling" of global biota; indeed, it would be accurate to characterize colonial expansion as the original bioinvasion! One can and should understand the botanical sciences as a significant legacy in the afterlives of empire.

In the context of the history of empire, the rise of the discourse of "invasive species" is particularly ironic. As colonialism ushered in new landscapes of empire, and new formations of naturecultures, nativist thinking re-engaged with national borders. Discourses of invasive species remains a prominent feature of the environmental afterlives of empire, as waves of nationalisms consume postcolonial worlds and colonial nations move to secure their borders. It is an ultimate act of irony, that after centuries of global expansion and ecological decimation of the planet, those very nations now insist on preserving the "new Europes" from newer immigrants from Asia, South America, and Africa (Crosby 1986; McNeely 2001). Tracking the histories of "invasive" rhetoric allows us to understand how plant and animal quarantine laws developed alongside national exclusion acts. Indeed, in the poignant cases of settler colonialism, national rewriting of history re-imagines the white settlers as the new "natives" that now relegate all others as foreign and undesirable. There is no pristine Eden here, no 
purity, no corner untouched by colonialism and its afterlives and the rapacious tentacles of modernity. Indeed, while the powerful have only now discovered an impending apocalypse, the colonized have long lived through apocalyptic nightmares of settler and neocolonialisms. I re-narrate this abbreviated history to highlight both the hubris of empire and its subsequent amnesia that together prevent us from a true botanical reckoning with our colonial past. Invasion biology is entirely a project of colonial nostalgia and return.

A true biological reckoning must acknowledge that we are all migrants now, all refugees of a ravaged naturecultural past, seeking to salvage our naturecultural present and futures. The constructions of natives, aliens, migrants, and refugees are all political constructions of the unequal afterlives of empire. The ravages of empire have transformed not only human and cultural landscapes, but also ecological ones, so no species is well adapted any more. We are all displaced, no longer living in the worlds we grew up in, our environment no longer familiar; we are all refugees, albeit in a very unequal and hierarchical worlds. The rise of the global right bespeaks a global anxiety about place. But rather than focusing on nativism, thinking in and out of empire reminds us that we are all adapted to worlds that no longer exist at "home." Indeed, the world that might feel like "home" might be thousands of miles away, on another continent. Reckoning with the false borders and boundaries of nations and nationalisms are not only about human worlds, but increasingly also about our co-inhabitants of the planet-the plants that feed us, the fabrics that clothe us, and the lumber that houses us. We need new naturecultural imaginations for our ruderal lives. But for that, we need to reckon with the botanical amnesia that consumes us.

\section{Notes}

${ }^{1}$ On radical feminist change in Boston in the 1970s, including the develop of university women's centers, see Spain (2011). Also in the 1970s, The Combahee River Collective coalesced in Boston, publishing their still valuable statement and founding Kitchen Table: Women of Color Press here before moving it to New York.

${ }^{2}$ Many thanks to Stacey Lantz, GCWS program manager, for all the work she put into hosting this roundtable. Thanks also to Wenxuan Xue, graduate student at Tufts University, for his editorial support in compiling this publication.

3 On the queer fandom of Chicana singer Selena, see Parédez (2009). 
${ }^{4}$ This and the following poem reprinted with the poet's permission.

5 Unlike this journal and Haraway, I use a hyphen between nature-cultures. While like them I believe that these entities are one, the hyphen flags that in the modern world, they are considered discrete.

${ }^{6}$ Among the most commonly cited ecofeminists are Vandana Shiva and Wangari Maathai, while Arturo Escobar's works are synonymous with post-development approaches. There are of course many others writers and thinkers in these traditions, including those offering critical perspectives, but they are not taken up or cited as often.

7 Environmental justice scholarship is re-emerging from in a variety of fields from anthropology to queer studies. The works of Laura Pulido in geography and Richard Bullard in sociology are among the key sources of inspiration. Much of this recent work focus on issues of race, gender, and the environment in the US and seldom draws on the much-longer trajectory of work in the non-Western world. I sense that it inadvertently risks Anglo-Eurocentrism in not taking transnationalism seriously. I flesh out this sense elsewhere.

${ }^{8}$ In the last few decades, many feminist-inspired fields and disciplines have focused on thinking naturescultures relations; among them are anthropology, geography, and political ecology.

9 I am greatly indebted to the wide range of researchers and activists I met through the Research and Monitoring in the Banni Landscape (RAMBLE) project, the Ashoka Trust for Research in Ecology and the Environment (ATREE), Sahjeevan, and the Banni Uchherak Maldhari Sangathan (BPUMS, or Banni Maldhari Breeders' Association).

${ }^{10}$ Organizations such as Gujarat Institute of Desert Ecology (https://gujaratdesertecology.com/), the Ashoka Trust for Research in Ecology and the Environment (ATREE)'s RAMBLE project (noted in the previous note), and Sahjeevan (http://sahjeevan.org/) are among those who do key research and advocacy work in the region.

\section{References}

Asher, Kiran. 2009. Black and Green: Afro-Colombians, Development, and Nature in the Pacific Lowlands. Durham, NC: Duke University Press. 
Asher, Kiran. 2017. "Thinking Fragments: Adisciplinary Reflections on Feminisms and Environmental Justice." Catalyst: Feminism, Theory, Technoscience 3 (2): 1-28. doi:10.28968/cftt.v3i2.28842.

—. 2018. "Fragmented Forests, Fractured Lives: Ethno-territorial Struggles and Development in the Pacific Lowlands of Colombia." Antipode 52 (4): 949-70. doi:10.1111/anti.12470.

- 2019. "Fieldwork." In Keywords in Radical Geographical Thought, edited by Sharad Chari, Paul Chatterton, Vinay Gidwani, Wendy Larner, Jamie Peck, Jenny Pickerill, Marion Werner, and Melissa Wright, 123-27. Wiley Publishers. https://onlinelibrary.wiley.com/doi/10.1002/9781119558071.ch22.

Asher, Kiran, and Joel Wainwright. 2019. "After Post-development: On Capitalism, Difference, and Representation." Antipode 51 (1): 25-44. doi: 10.1111/anti.12430.

Benería, Lourdes, and Shelly Feldman, eds. 1992. Unequal Burden: Economic Crisis, Persistent Poverty, and Women's Work. Boulder, CO: Westview Press.

Bharwada, Charul, and Vinay Mahajan. 2012. Let It Be Banni: Understanding and Sustaining Pastoral Livelihoods of Banni. Hyderabad, India: Research Unit for Livelihoods and Natural Resources: Centre for Economic and Social Studies.

Chen, Mel Y. 2012. "Masked States and the 'Screen' between Security and Disability." Women's Studies Quarterly 40 (1/2): 76-96.

Crosby, Alfred. 1986. Ecological Imperialism: Th Biological Expansion of Europe, 9001900. New York: Cambridge University Press.

Deer, Sarah. 2015. The Beginning and End of Rape: Confronting Sexual Violence in Native America. 3rd ed. Minneapolis: University of Minnesota Press.

Elbein, Saul. 2017. "The Youth Group That Launched a Movement at Standing Rock." New York Times, January 31, 2017.

https://www.nytimes.com/2017/01/31/magazine/the-youth-group-that-launched-amovement-at-standing-rock.html.

Geevan, C. P., Arun M. Dixit, and Chandra Shekhar Silori. 2003. Ecological Economic Analysis of Grassland Systems: Resource Dynamics and Management ChallengesKachchh District (Gujarat). Bhuj: Gujarat Institute of Desert Ecology. http://www.cescindia.org/doc-archiv/ee-cpg-report-full.pdf.

Grove, Richard. 1996. Green Imperialism: Colonial Expansion, Tropical Island Edens and the Origins of Environmentalism, 1600-1860. Cambridge: Cambridge University Press. 
Halberstam, Jack. 2011. The Queer Art of Failure. Durham, NC: Duke University Press. Haraway, Donna. 1985. "A Cyborg Manifesto: Science, Technology, and SocialistFeminism in the Late Twentieth Century." Socialist Review, no. 80, 65-108.

_ 1991a. "A Cyborg Manifesto: Science, Technology, and Socialist-Feminism in the Late Twentieth Century." In Simians, Cyborgs, and Women: The Reinvention of Nature, 149-81. New York: Routledge.

—. 1991b. "Gender' for a Marxist Dictionary: The Sexual Politics of a Word." In Simians, Cyborgs, and Women: The Reinvention of Nature, 127-48. New York: Routledge.

1991c. "Situated Knowledges: The Science Question in Feminism and the Privilege of Partial Perspective." In Simians, Cyborgs, and Women: The Reinvention of Nature, 183-201. New York: Routledge.

—. 2008. When Species Meet. Minneapolis: University of Minnesota Press.

Hiremath, Ankila J., and Siddhartha Krishnan. 2016. "India Knows Its Invasive Species Problem But This Is Why Nobody Can Deal with it Properly." The Wire, December 11, 2016. https://thewire.in/environment/invasive-species-prosopis-lantana.

Khubchandani, Kareem. 2016. "Terrifying Performances: Black-Brown-Queer Borrowings in Loins of Punjab Presents." Journal of Asian American Studies 19 (3): 27597. doi:10.1353/jaas.2016.0028.

Kim, Jina B. 2017. "Cripping East Los Angeles: Enabling Environmental Justice in Helena María Viramontes's Their Dogs Came with Them." In Disability Studies and the Environmental Humanities: Toward an Eco-Crip Theory, edited by Sarah Jaquette Ray, Jay Sibara, and Stacy Alaimo, 503-30. Lincoln: University of Nebraska Press.

Leroux, Darryl. 2019. Distorted Descent: White Claims to Indigenous Identity. Winnipeg: University of Manitoba Press.

Luciano, Dana, and Mel Y. Chen. 2015. "Introduction: Has the Queer Ever Been Human?" GLQ: A Journal of Lesbian and Gay Studies 21 (2/3): 183-207.

Maru, Natasha. 2016. "View from Below: Spatial Transformation and the State in the Banni Grassland of Western India." Master's thesis, St. Antony's College, Oxford University.

McNeely, Jeffery A. 2001. The Great Reshuffling: Human Dimensions of Invasive Alien Species. Gland: International Union for Conservation of Nature.

Morrison, Toni. 2008. What Moves at the Margin: Selected Nonfiction. Jackson: University Press of Mississippi. 
Napolitano, Regina. 2014. "Julio Salgado's 'Queer Butterfly' Featured in CAC's Art Series." Daily Bruin, January 8, 2014. https://dailybruin.com/2014/01/08/juliosalgados-queer-butterfly-featured-in-cacs-art-series.

Nelson, Eli. 2017. "'Walking to the Future in the Steps of our Ancestors': Haudenosaunee Traditional Ecological Knowledge and Queer Time in the Climate Change Era." New Geographies og (Posthuman): 133-38.

—. 2018. "Making Native Science: Indigenous Epistemologies and Settler Sciences and the United States Empire." PhD diss., Harvard University.

Parédez, Deborah. 2009. Selenidad: Selena, Latinos, and the Performance of Memory. Durham, NC: Duke University Press.

Perry, Ruth, Joyve Antler, Renee Fall, Laura Levine Frader, Carol Hurd Green, Barbara Haber, Alice Jardine, and Christiane Zehl Romero. 1996. "Inventing a Feminist Institution in Boston: An Informal History of the Graduate Consortium in Women's Studies at Radcliffe College." NWSA Journal 8 (2): 60-83. doi:10.2979/NWS.1996.8.2.60.

Piper, Karen. 2007. "Inuit Diasporas: Frankenstein and the Inuit in England." Romanticism 13 (1): 63-75. doi: 10.3366/rom.2007.13.1.63.

Puar, Jasbir K. 2007. Terrorist Assemblages: Homonationalism in Queer Times. Durham, NC: Duke University Press.

- 2012. "'I Would Rather Be a Cyborg Than a Goddess': Becoming-Intersectional in Assemblage Theory." philoSOPHIA: A Journal of Continental Feminism 2 (1): 49-66.

- 2017. The Right to Maim: Debility, Capacity, Disability. Durham, NC: Duke University Press.

RAMBLE. n.d. "About Banni." Accessed February 3, 2021.

https://bannigrassland.org/banni/.

Shah, Nayan. 2001. Contagious Divides: Epidemics and Race in San Francisco's Chinatown. Berkeley: University of California Press.

Simpson, Audra. 2016. "The State Is a Man: Theresa Spence, Loretta Saunders and the Gender of Settler Sovereignty." Theory \& Event 19 (4).

http://muse.jhu.edu/article/633280.

Spain, Daphne. 2011. "Women's Rights and Gendered Spaces in 1970 Boston." Frontiers: A Journal of Women Studies 32 (1): 152-78.

doi:10.5250/fronjwomestud.32.1.0152.

Spivak, Gayatri. 2012. An Aesthetic Education in the Era of Globalization. Cambridge, MA: Harvard University Press. 
Spivak, Gayatri. 1995. Imaginary Maps: Three Stories by Mahasweta Devi. New York: Routledge.

Stryker, Susan. 1994. "My Words to Victor Frankenstein above the Village of Chamounix: Performing Transgender Rage." GLQ: A Journal of Lesbian and Gay Studies 1 (3): 237-54. doi:10.1215/10642684-1-3-237.

Sturm, Circe. 2011. Becoming Indian: The struggle over Cherokee identity in the TwentyFirst Century. Santa Fe, NM: School for Advanced Research Press.

Subramaniam, Banu. 2014. Ghost Stories for Darwin: The Science of Variation and the Politics of Diversity. Champaign: University of Illinois Press.

Subramaniam, Banu, and Daniel Lanza Rivers. 2019. "Feminist Science Studies and the University: A Conversation with Banu Subramaniam and Daniel Lanza Rivers." Women's Studies: Futures of Feminist Science Studies 48 (3): 246-60. doi:10.1080/00497878.2019.1603986.

TallBear, Kim. 2015. "An Indigenous Reflection on Working beyond the Human/Not Human." (Dossier: Theorizing Queer Inhumanisms). GLO: A Journal of Lesbian and Gay Studies 21 (2/3): 230-35.

Taylor, Drew Hayden. 2016. Take Us to Your Chief: And Other Stories. Madeira Park, BC: Douglas \& Mclntyre.

Thorat, Ovi. 2017. "Shaping Landscapes through Development Interventions." Seminar, no. 695, 46-52.

Valles, Jesús I. 2019. "I'd Like To Keep It On, Please." The Accentos Review, Febuary 2019. https://www.acentosreview.com/February2019/jesus-i-valles-2.html.

Visweswaran, Kamala. 1994. Fictions of Feminist Ethnography. Minneapolis: University of Minnesota Press.

Visvanathan, Nalini, Lynn Duggan, Nan Wiegersma and Laurie Nisonoff, eds. 2011. The Women, Gender and Development Reader. 2nd ed. London, UK: Zed Books.

Wamsley, Laurel. 2020. "Sadness and Worry After 2 Men Connected to Butterfly Sanctuary Are Found Dead." National Public Radio, February 3, 2020.

https://www.npr.org/2020/02/03/802359415/sadness-and-worry-after-2-menconnected-to-butterfly-sanctuary-are-found-dead.

Wynter, Sylvia. 2003. "Unsettling the Coloniality of Being/Power/Truth/Freedom: Towards the Human, After Man, Its Overrepresentation-An Argument." CR: The New Centennial Review 3 (3): 257-337. doi:10.1353/ncr.2004.0015.

York, Geoffrey. 1991. People of the Pines: The Warriors And the Legacy of Oka. Boston, MA: Little, Brown. 


\section{Author Bios}

Kiran Asher is a biologist-turned-social scientist with three decades of field-based research on wildlife conservation, international development, and struggles for social change in Latin America and South Asia. Besides her monograph, her scholarly work appears in Antipode, Catalyst: Feminism, Theory, Technoscience, Feminist Studies, Feminist Review, GeoForum, Hypatia, and elsewhere.

Mel Y. Chen is Associate Professor of Gender and Women's Studies and Director of the Center for the Study of Sexual Culture at the University of California, Berkeley. Their writing includes Animacies: Biopolitics, Racial Mattering, and Queer Affect (Duke UP, 2012), journal articles in ISLE, Medical Humanities, TSQ, GLQ, South Atlantic Quarterly, Women in Performance, as well as anthologies and exhibition catalogs.

Kareem Khubchandan is Mellon Bridge assistant professor of theatre, dance, and performance studies, and women's, gender, and sexuality studies at Tufts University. He is the author of Ishtyle: Accenting Gay Indian Nightlife (University of Michigan Press, 2020), co-editor of Queer Nightlife (forthcoming, University of Michigan Press), and curator of "Queer Aunty Studies" (www.queerauntystudies.com).

Eli Nelson (Mohawk) teaches in American Studies and Science and Technology Studies at Williams College. His current book manuscript, Sovereign Knowledge: Indigenous Epistemologies and Native Science in the United States Empire, traces the history of Indigenous scientific knowledge production across different national contexts and disciplines in the 19th and 2oth centuries. In addition to the history of Native science, Professor Nelson works on critical Indigenous theory, as well as Indigenous science fiction and futurism, and gender and sexuality.

Banu Subramaniam teaches in the Department of Women, Gender, Sexuality Studies at the University of Massachusetts Amherst. Her work explores the philosophy, history, and culture of the natural sciences and medicine as they relate to gender, race, ethnicity, and caste. Her latest research rethinks the field and practice of botany in relation to histories of colonialism and xenophobia and explores the wide travels of scientific theories, ideas, and concepts as they relate to migration and invasive species. 